\title{
Chapter 10 \\ The Magical Fruits: Establishing \\ a Narrative Play Frame for Mutual \\ Problem Solving
}

In this chapter, we will analyze an activity from initiation to conclusion. We will focus our analysis on (i) how the teacher establishes a narrative, imaginary, frame for the activity, (ii) how children participate and contribute to this activity, (iii) what didaktikal challenges are actualized and what support the children are faced with in the activity, including what contents are constituted, and (iv) what the implications of the activity are for children's development.

One preschool teacher and nine children, aged approximately 4-5 years, participate in the activity. The activity is carefully planned by the teacher and it starts with someone ringing the doorbell at the preschool. The children run to the door to open. When they open the door they find an envelope left on the doorstep. The children give the envelope to the teacher:

\section{Excerpt 10.1: Introducing the Narrative Frame and the Challenge Posed}

\begin{tabular}{|c|c|c|}
\hline 17 & ANNA: & $\begin{array}{l}\text { Should I read now? 'Cause there were these small messages Now, let's see. Can } \\
\text { you hear? Hi there, all you creepy children at the Galaxy. My name is } \\
\text { mischievous Ralf. And I've left magical fruit for you. But! (raises her index } \\
\text { finger) in order for you to get the magical fruit, you must first get past all creepy } \\
\text { and dangerous obstacles that I have magically conjured on your preschool. } \\
\text { Every obstacle. At every obstacle, I've left a letter with a mission. If you do not } \\
\text { solve the mission (raises her index finger) you will not be able to pass the } \\
\text { obstacle. If you manage to get to the magical fruit, you will, as soon as you take } \\
\text { a bite, receive a magical power. (The children start jumping with both feet) Wait, } \\
\text { wait, wait. What power you get when you take a bite from the fruit is up to you to } \\
\text { decide. And then the letter ends like this. Good luck and watch out for all creepy } \\
\text { and viscious monsters (raises her index finger) lurking around the corners. } \\
\text { Mohahaha (laughing with a rough voice) Ralf. }\end{array}$ \\
\hline 18 & Gustav: & (finds a message on the floor and picks it up) \\
\hline 19 & ANNA: & $\begin{array}{l}\text { Now let's see. Wait, wait, back up a little. Then Gustav gets to... do you want to } \\
\text { read Gustav? Shall I read the mission? You all have to find ten round objects. } \\
\text { Together }\end{array}$ \\
\hline
\end{tabular}




\begin{tabular}{l|l|l}
\hline 20 & Minna: & What are objects? \\
\hline 21 & ANNA: & Ten round things \\
\hline 22 & Annika: & Kind of like this (takes a doll made from a paper roll from a shelf) \\
\hline 23 & ANNA: & Yes, exactly \\
\hline 24 & Nathan: & That one's mine (points at a doll on a shelf) \\
\hline 25 & ANNA: & $\begin{array}{l}\text { Listen. If you find that, you'll receive a magical power that allows you to pass the } \\
\text { red-hot stones (points at four red paper sheets on the floor behind the children). }\end{array}$ \\
\hline 26 & Children: & Oh! \\
\hline 27 & ANNA: & $\begin{array}{l}\text { Can you find ten round things together? And then we meet here, we can collect } \\
\text { the things here }\end{array}$ \\
\hline
\end{tabular}

The teacher introduces the activity through reading the letter (turn 17). Reading the letter triggers the collective activity that follows, in which the children ponder over real problems (as is) in the context of as if. Establishing the narrative, imaginary, frame, she institutes some ground rules; in order to succeed every obstacle needs to be overcome, through succeeding with a task, a reward in the form of a magical skill is offered, which takes the children past the obstacle and towards the goal of a magic skill of their own choice. The activity is organized by rules, dictated in the letters. However, it also includes open-endedness in that children are to decide what magical power they will receive after finishing all the tasks and taking a bite of the fruit (and, thus, how the play can continue and evolve). Rules, as Vygotsky (1933/1966) has clarified (see also, van Oers, 2014) are constituents of every play; they co-constitute what is the nature of the play played. An imaginary realm is established; but the children are directly addressed ("Hi there, all you creepy children at the Galaxy"). Hence, the story initiated enrolls the children; they are constituted as recipients of the challenge, and thus the agents of the story. In this way, they are placed in a position where they have agency (Clarke et al., 2016) to 'tell'/develop the story, rather than merely listening to a story told. Phrased differently, the teacher through her introduction of the activity engages the children in a mutual play project (triggering collaborative play and problem solving). That the children are engaged in doing so is evident in their eagerness to start acting (they can hardly contain themselves, jumping up and down, turn 17).

Through planting a letter at every challenge the teacher makes reading necessary to the development of the play, as argued by Vygotsky (1997) to be critical to making it relevant to children already in the preschool age (see Chap. 9 of the present volume). The task is also constituted in a way that makes it necessary for the children to collaborate in solving it (turn 19). This is a more challenging task than for a child to solve it by him or herself (see Björklund, 2014, for an elaboration). Engaging children in mutual activities is key to preschool activities, since its groupbased nature is one of the characteristics of how this institution organizes for children's experience and development (Pramling Samuelsson \& Pramling, 2013). The initial challenge posed is for the children to find "ten round objects. Together" (turn 19). In response, one of the children asks "what are objects (Swedish: "föremål", turn 20). Responding, the teacher reformulates the task in terms of "ten 
round things" (turn 21). Another child shows a doll made from a paper roll, suggesting "kind of like this" (turn 22). The teacher confirms that this is an example of an object, as relevant in the activity: "yes, exactly" (turn 23). Hence, without experience of the actual term ("object"), the child can show her understanding, allowing her to participate in the evolving elaboration of the task (the activity).

In addition to showing how the mutual activity is established through introducing a narrative frame, Excerpt 10.1 shows how some conceptual knowledge is necessary for participating in it. In response to the child clarifying her being unfamiliar with the abstract category of "objects", the teacher unpacks it through reformulating it in more familiar terms ("things"). Another child finds and shows an example. The concept of "objects" is thus introduced and explained within the frame of the activity, as a part of setting the activity into motion.

There is some tension between the mutual task and individual engagement (turn 24: "that one's [pointing at an object] mine"). The teacher reiterates the reason for finding the objects (turn 25), that is, clarifies what role this plays in the play (the imaginary narrative): "If you find that you'll receive a magical power that allows you to pass the red-hot stones", and, through pointing at some props (four red sheets of paper on the floor, turn 25), coordinates as if (the challenge posed within the story) and as is (the actual paper on the floor). Finally, the teacher reminds the children of the collaborative nature of the challenge: "Can you find together ten round things?" (turn 27).

In this way, the activity, its rules, and challenges, are introduced. An imaginary realm is established for the children to explore. The children run around collecting objects, which they bring to the teacher. She again gathers the children to investigate what they have collected:

\section{Excerpt 10.2: Counting Objects}

\begin{tabular}{l|l|l}
\hline 33 & ANNA: & Oh oh oh, now let's see. We should have ten. Come, let's count \\
\hline 34 & Lotta: & One two three four five six seven eight nine (points down in the can) \\
\hline 35 & Girl: & Ten. We have ten! \\
\hline 36 & Gustav: & One two three four five six seven eight \\
\hline 37 & $\begin{array}{l}\text { ANNA and } \\
\text { several children: }\end{array}$ & Nine (ANNA holds an object in her hand) \\
\hline 38 & Child: & $\begin{array}{l}\text { We need one more (two of the girls get up and run to the magnetic board } \\
\text { to get more objects) }\end{array}$ \\
\hline 39 & ANNA: & And ten (lifts and shakes the can with the things in it) \\
\hline
\end{tabular}

The task of finding ten round things actualizes two mathematical features. The first challenge is to discern the shape of objects and decide whether an object fits the criterion. The paper roll found by one child was considered a suitable example ("yes, exactly", Excerpt 10.1, turn 23) without further discussion. However, taking a mathematical perspective, the shape is rather a cylinder with a circular (round) basis. The children seem to know what shape to look for and have no trouble finding 
round objects, neither are the shapes of their objects found challenged, even though the shape of the container may be included in the set of ten round objects.

The second mathematical challenge consists of the children being asked to count the objects they have gathered together. One of the children arrives at "nine" (turn 34), while another child suggests they have "ten" (turn 35). However, after some other suggestions (turns 36-38), the children decide they need one more, and two of the children set off to find the missing object. However, before they can do so, the teacher suggests they already have ten (turn 39). She says so while shaking the container in which they have placed the other objects. Hence, what is the reason for the discrepancy between the participants in counting is whether they count also the container as an object (the teacher does so while at least some of the children do not).

\section{Excerpt 10.3: Negotiating How to Go On}

\begin{tabular}{l|l|l}
\hline 40 & ANNA: & $\begin{array}{l}\text { Wait wait wait. We have ten. We succeeded with the mission. And you know } \\
\text { what, the magical power is so that these stones are red-hot, so you cannot walk } \\
\text { on them. But Gustav, who was first, got the magical power, so that when he } \\
\text { takes a, when he stands on the stone (points at the first red paper sheet on the } \\
\text { floor) it is no longer red-hot. (Gustav takes a careful step onto the first sheet, } \\
\text { then jumps on to the other sheets. He is followed by other children, someone } \\
\text { also walk on the floor) Stop, psst, no, there's a lot of sharks in the sea, stay on } \\
\text { the stones (the girl stepping on the floor backs up on the sheet) }\end{array}$ \\
\hline 41 & Esther: & (standing on the sheet behind Gustav): How are we gonna pass? \\
\hline 42 & ANNA: & How are we gonna pass? How should we do? \\
\hline 43 & Esther: & There, there (pointing at something on the other side of the room) \\
\hline 44 & Nathan: & I know, we can go by boat! \\
\hline 46 & Annika: & I know what we should do! \\
\hline 47 & ANNA: & What should we do then? \\
\hline 48 & Esther: & We have to be limber \\
\hline 49 & Gustav: & I have a plan! \\
\hline 50 & ANNA: & Mm. \\
\hline 51 & Gustav: & We can jump on the sharks all the way there (points across the room) \\
\hline 52 & Eyla: & (takes a step to the first sheet) \\
\hline 53 & ANNA: & $\begin{array}{l}\text { Now you go. Good Eyla, you can go on (Eyla goes to the next sheet) so we can } \\
\text { see how many children we can get there }\end{array}$ \\
\hline 54 & Gustav: & $\begin{array}{l}\text { I know, we can sneak (makes sneaking movements with his hands, reaches } \\
\text { forward and then softly pulls his arms back to his body) }\end{array}$ \\
\hline 55 & & $\begin{array}{l}\text { (The children stand two and two on each sheet and one child is on the carpet } \\
\text { with ANNA) }\end{array}$ \\
\hline 56 & ANNA: & Wait, let's see, what should we do now? \\
\hline 58 & Eyla: & (sneaks across the floor) \\
\hline 59 & Eyla: & $\begin{array}{l}\text { No, you cannot go there, there are sharks! (waves her hand for Eyla to come } \\
\text { back. }\end{array}$ \\
\hline
\end{tabular}


By lifting and shaking the container the teacher attempts to make the children aware of the missing object. She then concludes that they "have succeeded with the mission" (turn 40). Shifting back from as is (they now, in fact, have ten round objects), the teacher continues meta-communicating but now elaborates as if: explaining how with the magical power acquired through solving the problem, the stones cease to be red-hot, making it possible for the children to go on in their quest (turn 40).

When the children start walking, some stepping beside the red papers on the floor, the teacher introduces additional rules, or provides a clarification of the rules, for the children to relate to: "Stop, psst, no, there's a lot of sharks in the sea, stay on the stones" (turn 40). While they explore as if, there are things to adhere to, without which the play would soon lose all appeal (without any limitations/rules, there is no mutual story to play within). The teacher's comment is met by a child asking: "How are we gonna pass?" (turn 41). Another child suggests, "we can go by boat" (turn 42). However, this suggestion, which may be feasible within the frame of the story, is objected to by another child arguing that "but there is no boat" (turn 43). What is at stake here, play-wise, is whether to play with the props available or whether it is possible to introduce, through fantasy, new objects other than those represented by the props available. This question is thus briefly negotiated by the children. More suggestions are given by the children, that "we have to be limber" (in Swedish: "smidiga"), or that "I have a plan! We can jump on the sharks all the way there" (pointing towards the end of the room) (turns 49 and 51). At this point, the participants have not established temporarily sufficient intersubjectivity (Rommetveit, 1974) to go on with a joint activity (in this case, proceed past the solved problem). The children continue to try to find solutions to the problem they face. One of the children enacts (pretends) that she sneaks over the space before her (turn 57). However, this solution is not accepted by the teacher, who responds that "no, you cannot go there, there are sharks!" (turn 58). In response, the girl sneaks back to her previous position. Notably, the child does not leave the imaginary realm in response to the teacher's objection; even on her way back to her original position, she sneaks (i.e., acts within the play-world, as if to be careful not to wake or notify the sharks, turn 59). After some further consideration, they all pass on the stones (sheets). The teacher asking (in turn 42) - actually repeating a child's question (turn 41) - how they are to pass, triggers the children to contribute to the evolving narrative, trying out different solutions to the problem faced. They now face a new challenge:

\section{Excerpt 10.4: Solving the Problem Individually or Collectively}

\begin{tabular}{l|l|l}
\hline 68 & ANNA: & $\begin{array}{l}\text { What, have we got the new mission? (Annika gives her a folded paper). Now } \\
\text { let's see. Ah. Together you must find five (lifts five fingers) red things. Wait, } \\
\text { listen. And five blue things. 'Cause then you can make all the monster-fish } \\
\text { swimming there and are invisible, we do not see them, fall asleep in the brook! } \\
\text { So that we can cross over. Do we solve this mission? }\end{array}$ \\
\hline 69 & Annika: & There's one (points at letters in different colors posted on the wall) \\
\hline 70 & ANNA: & $\begin{array}{l}\text { Yes, but we have to get five things. Blue. Things (the children start moving } \\
\text { around) and five red. You can get things from in there also (points towards the } \\
\text { room behind them. The children run and get red and blue things. One of the } \\
\text { girls takes down a large box and gives it to ANNA) }\end{array}$ \\
\hline
\end{tabular}




\begin{tabular}{|c|c|c|}
\hline 71 & Minna: & $\begin{array}{l}\text { Two red and one blue (puts the things in the box. Other children also put their } \\
\text { things in) }\end{array}$ \\
\hline 72 & ANNA: & $\begin{array}{l}\text { Oh oh oh, and that one was blue (sits down on the floor)... Good Nathan. Oh } \\
\text { how many. Shall we see now, children? }\end{array}$ \\
\hline 73 & Annika: & $\begin{array}{l}\text { (stands on the table, turns to the teacher filming the activity) Hey, you're } \\
\text { standing on the sharks }\end{array}$ \\
\hline 74 & ANNA: & $\begin{array}{l}\text { Annika and Minna and you, now we have to count so that we have five red and } \\
\text { five blue }\end{array}$ \\
\hline 75 & Eyla: & (drops a large cuddly animal among the things on the floor) \\
\hline 76 & ANNA: & $\begin{array}{l}\text { Oh, do you take that one? (hands back the animal to Eyla). Wait a bit (the } \\
\text { children talk at the same time and some get more things) }\end{array}$ \\
\hline 77 & Annika: & One two (moves the objects in turn) \\
\hline 78 & ANNA: & Two \\
\hline 79 & Annika: & Three \\
\hline 80 & ANNA: & Three four (together with the children) five. Good. \\
\hline 81 & Children: & Six seven eight (Anton brings three more red objects) \\
\hline 82 & ANNA: & $\begin{array}{l}\text { You'll have to return them, Anton, we already have five. Good. Five red and } \\
\text { then we need... }\end{array}$ \\
\hline 83 & Anton: & I had taken these three before they took those red \\
\hline 84 & ANNA: & But it was swell. Now we've got lots of things \\
\hline 85 & Eyla: & ANNA, you'll have to be a bit quiet, they're sleeping! \\
\hline 86 & ANNA: & $\begin{array}{l}\text { Now we need five blue things (turns to Nathan and then to Annika) Annika, } \\
\text { Annika, put back the shoes and look here what Nathan has got }\end{array}$ \\
\hline 87 & Nathan: & $\begin{array}{l}\text { My cuddly animal! (holds a blue box with many things in. takes out a } \\
\text { green-blue cuddly animal) }\end{array}$ \\
\hline 88 & ANNA: & $\begin{array}{l}\text { One. Blue (points at the cuddly animal). Two (points at Gustav, who holds a } \\
\text { blue cup) and then we have (turns around a plastic letter) someone came } \\
\text { with... }\end{array}$ \\
\hline 89 & Esther: & I took it down! \\
\hline 90 & ANNA: & $\begin{array}{l}\text { An E. Three, four (holds and points at something small) and five. We found a } \\
\text { lot }\end{array}$ \\
\hline 91 & Annika: & $\begin{array}{l}\text { And five (has climbed up on the table and points at something on the wall) and } \\
\text { five }\end{array}$ \\
\hline 92 & ANNA: & Listen, are you gonna sneak past now \\
\hline 93 & Children: & (hurry to a door, someone says) I take it! I was gonna take it actually \\
\hline 94 & ANNA: & We're lucky they're asleep, these fish \\
\hline 95 & Anton: & Run! \\
\hline 96 & ANNA: & Sch, sch, sch \\
\hline 97 & Gustav: & I think it chewed a bit on my leg \\
\hline 98 & ANNA: & $\begin{array}{l}\text { Did it? No, they fell asleep, we solved the mission. Listen, sch, mission three. } \\
\text { A volcano has erupted so that the whole ground is full of red-hot lava (someone } \\
\text { is heard carrying their breath). Wait. }\end{array}$ \\
\hline 99 & Lotta: & I cannot do this \\
\hline 100 & ANNA: & $\begin{array}{l}\text { There's a boat on the other side that you can use. But then you first need to } \\
\text { collect ten elongated things }\end{array}$ \\
\hline 101 & Annika: & (raises her ten fingers) \\
\hline
\end{tabular}


The new task given is to find "five red things" and "five blue things" (turn 68). These tasks are motivated by the evolving fantasy narrative: "“cause then you can make all the monster fish swimming there, and are invisible, fall asleep in the brook! So then we can cross over" (turn 68). The analogically recurring challenges weave the events together into a narrative of a prolonged journey (an intertextual link, cf. Mercer \& Littleton, 2007). The teacher also implicitly reminds the children of another important feature of the activity: its group-based nature: "Do we solve this mission?" (turn 68), that is, the problem is to be solved mutually ("we"), not by any individual child.

The children search the room and the adjacent room for things that are blue or red. The teacher acknowledges their contributions and suggests they count how many they now have (turn 72). At this point, one of the children addresses the other preschool teacher, who, operating the video camera, has remained silent for the duration of the activity: "you're standing on the sharks" (turn 73). This may be seen as an attempt to enroll also this teacher in the activity. However, she remains silent and the activity proceeds. While the participating teacher (turns 72 and 74) orients to as is, the child here (turn 73) orients to as if.

Counting together with the children, the teacher concludes that they now have five objects (turn 80). However, one of the children arriving with three red objects continues counting: "six, seven, eight" (turn 81). In response, the teacher tells him that he needs to put them back, "we already have five [...] and then we need" (turn 82). The boy is not immediately content with this suggestion, objecting "I had taken these three before they had taken those red" (turn 83). This illustrates an important feature of the task as group-based: it is more challenging than collecting a certain number of objects; one also needs to relate the objects one brings to the ones brought by the other children to make up the requested amount. Mitigating the potential disappointment in the boy, the teacher suggests that "But it was swell. Now we've got lots of things" (turn 84). We can in this example see the potential tension between including all children as important participants in the play tasks and to follow the designated rules of the play - here manifested as a task to collect only five red things.

As seen in Excerpts 10.2 and 10.4, the children are able to count and determine a set of ten objects by counting them one-to-one. However, a challenge is to adjust their own collecting to that of the other children. This requires paying attention to the collected number of objects, where the set of objects one child has collected is only one part of the whole (five in the activity shown in Excerpt 10.4, and ten in the activity shown in Excerpt 10.2). To solve the task, it is necessary for the children to establish temporarily sufficient intersubjectivity concerning what the task is about and how each participant's actions relate to this task. Otherwise, they will be engaged in parallel activities, trying to solve the task by themselves, individually, which will not work within the premises of the task given in the story they engage in. It is a treacherous task, since it seems easy enough for preschool children to solve, but actually requires conceptual knowledge of numbers as a collection of varying items and varying quantities that have to be seen as units constituting the whole set of five (a competence not shared by all Swedish 5-year olds, see Björklund, 2014). 
One of the children addresses the teacher, exclaiming: "you'll have to be a bit quiet, they're sleeping!" (turn 85). Hence, remaining in the as-if mode of the narrative (cf. turn 68), she asks the teacher to remain in character and not break the narrative thread. This and the previous exchanges thus also illustrate how there is no problem in posing conceptual challenges to children within the frame of a fantasy story, but if stepping out of this frame, the nature of the activity may need to be re-negotiated (meta-communicated) (cf. Björklund et al., 2018, for an analysis of teachers' conceptually challenging acts in the context of children's play).

Having collected five red objects, the children now set out to collect five blue ones. They swiftly find these objects. The teacher, mirroring one of the children's comments (in turn 85), now comments on the children's exalted state: "Listen, are you gonna sneak past now" (turn 92), "we're lucky they're asleep, these fish" (turn 94), and "sch, sch, sch" (turn 96). Hence, like the children previously reminding the teacher of sticking to the play-frame, the teacher now reminds the children to do so. In order to remain engaged in a mutual activity (play project), these metacommunicative hints tend to recur in participants' talk. Passing over the sleeping monster fish, one of the children suggests that "I think it chewed a bit on my leg" (turn 97). "Did it?", asks the teacher, before objecting that "no, they fell asleep, we solved this mission" (turn 98). Restating the relation between the narrative and the conceptual problem (solving the task puts the monster fish to sleep allowing safe passage) here evidently takes precedence over incorporating the child's suggestion into the narrative (e.g., suggesting that even while solving the problem, putting the fish to sleep, the loud sounds made by the children made them start to awake again, making it necessary to hurry silently).

The children now face the third challenge: "A volcano has erupted so that the whole ground is full of red-hot lava" (turn 98), but "there's a boat on the other side that you can use. But then you first need to collect ten elongated things" (turn 100). That the challenges posed, at a collective level, could be in what Vygotsky (1998) refers to as the children's zone of proximal development is indicated by the span of variation in responses, with one child stating that "I cannot do this" (turn 99), while another child shows ten with her fingers (turn 101).

\section{Excerpt 10.5: Social Concerns}

\begin{tabular}{l|l|l}
\hline 118 & ANNA: & $\begin{array}{l}\text { That was elongated, exactly (follows with her finger along the contours of a } \\
\text { sandal) Nine and ten, good. Listen. Now we're gonna open here (the children } \\
\text { gather at the door) Wait wait, now we succeeded with this (reads from the } \\
\text { letter) If you succeed with this, it says, then one of you get a magical power } \\
\text { so that one of you can walk on the magical and red-hot lava and get the boat }\end{array}$ \\
\hline 119 & Annika: & (raises her hand) I can! \\
\hline 120 & $\begin{array}{l}\text { Three other } \\
\text { girls: }\end{array}$ & (raise their hands and say in unison) I can \\
\hline 121 & ANNA: & $\begin{array}{l}\text { One, one child (the children jump with both feet and raise their hands } \\
\text { shouting" I can") }\end{array}$ \\
\hline 122 & ANNA: & Wait, can't you try to decide together whom among you... \\
\hline 123 & Lotta: & I know, Esther (points at Esther). \\
\hline
\end{tabular}




\begin{tabular}{l|l|l}
\hline 124 & $\begin{array}{l}\text { Several } \\
\text { girls: }\end{array}$ & (point at Esther) Esther \\
\hline 125 & ANNA: & $\begin{array}{l}\text { Good that you agreed so quickly. And you know what, have to get the boat. } \\
\text { You're the only one who can walk on the lava so you'll have to get the boat } \\
\text { and take your friends across to the other side. Okay, let's see (opens the } \\
\text { door). Then we have to stand here waiting. One at a time can go with Esther } \\
\text { in the boat (Esther runs and gets a large box on wheels and rolls it back to the } \\
\text { children) Who'll pass over first? }\end{array}$ \\
\hline 126 & Children: & Me! \\
\hline 127 & ANNA: & $\begin{array}{l}\text { Annika, good, jump in (Annika sits down in the box) Esther takes her across } \\
\text { to the other side (Esther rolls the box with Annika in it over to the other side } \\
\text { of the room. The children laugh) }\end{array}$ \\
\hline 128 & ANNA: & $\begin{array}{l}\text { Oh oh, what red-hot lava. Next, next friend across (another child sits down in } \\
\text { the box and is rolled across the room). How many friends have crossed? One, } \\
\text { and then there's one more, how many is that? (someone says" two") Two } \\
\text { friends }\end{array}$ \\
\hline 129 & Minna: & I go last \\
\hline 130 & ANNA: & Oh, how nice. How many friends are over there now? \\
\hline 131 & Children: & Three \\
\hline 132 & ANNA: & Three. Get one more \\
\hline 133 & Boy: & Then Esther's gonna drive herself also \\
\hline 134 & ANNA: & Esther has the magical powers, so she can walk on the lava \\
\hline 135 & Eyla: & (dances across the floor) \\
\hline 136 & ANNA: & $\begin{array}{l}\text { No it's only Esther who has the magical power. Now let's get another friend. } \\
\text { How many children is it over there now? }\end{array}$ \\
\hline 137 & Children: & Four! \\
\hline 138 & ANNA: & And with Gustav you have...? \\
\hline 139 & Children: & Five! \\
\hline 140 & Minna: & You can go before me \\
\hline 142 & ENNA: & And then we get another friend \\
\hline 143 & ANNA: & Six \\
\hline 144 & Minna: & $\begin{array}{l}\text { That's six friends over there now (turns to the next boy) Be careful so you } \\
\text { don't fall in (turns to the children across the room) Six friends }\end{array}$ \\
\hline But you're standing on the lava! \\
\hline Nowan & (sits down in the box) \\
\hline
\end{tabular}

Having together collected ten elongated objects of various kinds (e.g., sandals and a pearl necklace), the teacher tells the next step of the adventure: "listen. Now we're gonna open here" - the children flocking at the door - "wait wait. Now we succeeded with this" (turn 118). She now reads from the new letter found at the door: "if you succeed with this, it says, then one of you get a magical power so that one of you can walk on the magical and red-hot lava and get the boat" (turn 118). Again, text and reading are introduced in the play activity as necessary (Vygotsky, 1997), containing information about the next challenge faced, making it possible to go on with the adventure. Several children announce their willingness to be the one to do 
so (turns 119-120). The teacher is not content with this way of solving the issue of who is to be given the task of fetching the boat. To simply give the mission to the child first speaking or speaking the loudest is contrary to preschool tradition. Rather, the children are expected to arrive at a solution that is considered fair: "one, one child" and "wait, can't you try to decide together whom among you..." (turn 122). Several children now suggest "Esther". The teacher accepts this suggestion: "good that you agreed so quickly" (turn 125). It may be questioned whether the voices of all participating children were heard in this case or whether some children agreed on what may be a popular girl. The rationale of the task is explained to Esther: "you know what, have to get the boat, you're the only one who can walk on the lava, so you'll have to get the boat and take your friends across to the other side" (turn 125).

Esther starts to take her friends over the lava and the teacher makes the children attend to how many have crossed and how many remain: "get one more" (turn 132). In response to this suggestion, one of the children suggests that "then Esther's gonna drive herself also" (turn 133). Rather than simply accepting this logical conclusion, the teacher reframes/recontextualizes the problem within the rationale of the evolving narrative: "Esther has the magical powers, so she can walk on the lava" (turn 134). Hence, the teacher adheres to a rule of the play (following the texts stating the nature of the problems faced and the consequences of their solution). Another girl starts dancing over the floor (the lava). This breach of the narrative frame is objected to by the teacher: "No, it's only Esther who has the magical power" (turn 136). To what extent participants in a play are to follow a set of rules and to what extent also these can be renegotiated within the frame of the story (and outside it, if taking a meta-perspective) are always potentially at stake in play activities. Theoretically speaking, a tension recurs between temporarily sufficient intersubjectivity and alterity (i.e., between agreeing on the premises of the play activity in order to be able to create and maintain a mutual play project, on the one hand, and rethinking premises and taking action in unexpected and diverse directions during an activity, on the other).

Other examples of this tension between intersubjectivity and alterity was evident in Excerpt 10.3 (turns 57-58), when a child and the teacher negotiated whether it was possible to sneak past the sharks, and in Excerpt 10.4 (turns 97-98) where a child and the teacher negotiated whether the monster fish may have taken a piece of the child's leg as he crossed the brook. It is important to realize that the tension between intersubjectivity and alterity is always potentially at stake in human interaction (Wertsch, 1998), for instance in play projects, and not take a normative stance as one being better than the other. Mutual play projects can proceed whether being responsive to alterity or not; however, the play develops differently contingent on this response.

In her comments to the children, the teacher fluctuates between as is (e.g., how many children are in one place and how many in another and that there are different conditions/rules for different actors in the play), and as if (e.g., the children needing to be aware to not fall into the hot lava, turn 143). 


\section{Excerpt 10.6: Suggestions Not Taken Up}

\begin{tabular}{|c|c|c|}
\hline 149 & ANNA: & Across with the last friend \\
\hline 150 & Child: & Nine \\
\hline 151 & ANNA: & What about me? \\
\hline 152 & Esther: & I can come and get you \\
\hline 153 & ANNA: & $\begin{array}{l}\text { Ah, nice. Take me across (sits down in the box and is rolled across the room. } \\
\text { She suddenly points at the window) Look! Did you see the monster? (the } \\
\text { children run to the window) I thought I saw a monster }\end{array}$ \\
\hline 154 & Annika: & I've found a letter \\
\hline 155 & ANNA: & There wasn't any monster, right? \\
\hline 156 & Child: & Monsters are invisible \\
\hline 157 & ANNA: & Oh, that's right. Good, thanks Esther \\
\hline 158 & Annika: & I got the letter (hands it to ANNA) \\
\hline 159 & ANNA: & What does it say? Mission... \\
\hline 160 & Children: & Four \\
\hline 161 & ANNA: & Which door did you find it on? \\
\hline 162 & Children: & That (points at a closed door) \\
\hline 163 & ANNA: & Then I think that that's maybe where we should go \\
\hline 164 & Gustav: & Yes, maybe we get magical powers and kill the monsters \\
\hline 165 & Eyla: & Sch, sch (covers her mouth with her index finger) \\
\hline 166 & ANNA: & $\begin{array}{l}\text { Sch, listen. Listen and I'll read the mission. In the cave over there I have } \\
\text { hidden the magical fruit. In order for you to get to it, you first have to, listen, } \\
\text { get through the creepy tunnel. Listen, THIS is important I heard or saw when I } \\
\text { read this. You have to be completely silent (holds her index finger over her } \\
\text { mouth) so that you don't wake the invisible dragon who sleeps in there. }\end{array}$ \\
\hline 167 & Lotta: & We need to have magical powers and kill the monster \\
\hline 168 & ANNA: & $\begin{array}{l}\text { Listen. If you succeed in getting the magical power, if you succeed in getting } \\
\text { the magical fruit, you will as soon as you take a bite of it receive a magical } \\
\text { power, that you decide by yourself }\end{array}$ \\
\hline 169 & Lotta: & And kill the monster \\
\hline 170 & ANNA: & $\begin{array}{l}\text { And then you also get, it says here, a power that makes so that when you talk, } \\
\text { the dragon cannot hear you }\end{array}$ \\
\hline
\end{tabular}

Having taken all the children across the lava, the children count "nine" (turn 150). The teacher responds, "what about me?" (turn 151). In a sense, the children's omission of the teacher when making sure all participants have crossed the lava in the boat is analogous to them not paying attention to the container as an object in Excerpt 10.2. However, in this case they may not consider the teacher a participant in the play, but rather as a director or storyteller, and this may be why they do not count her as an additional agent they need to take across. Esther comes to get the teacher in the boat. On the way over, the teacher exclaims that she thinks she saw a monster in the window. The children investigate. While doing so one of the children finds a new letter. Following up on her playful suggestion (turn 155), a child responds that "monsters are invisible" (turn 156), implying that the teacher therefore cannot have seen one. This is again one small instance of participants negotiating 
the premises of the play. Having agreed on the invisibility of monsters, the teacher asks what the letter says. The children point out on which door the letter was attached. The teacher then suggests that "then I think that that's maybe where we should go" (turn 163). In this way, the as-if world of the narrative (the letter with the challenges and the evolving story) and the world of as is (the actual milieu used as props in the play) are coordinated (cf. above).

One of the children is eager to go on with the adventure, suggesting that "yes, maybe we get magical powers and kill the monsters" (turn 164). This suggestion combines a constituent of the evolving narrative (i.e., that magical powers are acquired and that monsters are faced) with a novel feature (killing the monsters). This can be seen as an example of creativity (Vygotsky, 1930/2004) and the tension between intersubjectivity and alterity. The suggestion that they may acquire magical powers, making them capable of killing the monsters, is not responded to by the teacher. This non-response (which as such is a form of response) can be read as an indicator that this suggestion is not aligned with by the institution sanctioned forms of play. This kind of tensions places the activity in an institutional setting to which participants in different ways orient and are responsive. Differences in this regard can be seen as varying degrees of sensitivity to how to contextualize play actions in a preschool setting. Playing in preschool is also a way of being socialized into certain perspectives and values (including what is good and bad play, respectively). The teacher, so to speak, tries to curb the children's excitement ("sch, listen... [...] listen THIS is important...") while explaining the rationale of the new task: "you have to be completely silent so that you don't wake the invisible dragon who sleeps in there" (turn 166). The children are eager to go on with the adventure; another child now also suggests that "we need to have magical powers and kill the monster" (turn 167, cf. turn 164). Again, this suggestion to kill the monster is met by a nonresponse by the teacher. Instead, she explains what the letter says: "Listen. If you succeed in getting the magical power, if you succeed in getting the magical fruit, you will as soon as you take a bite of it receive a magical power, that you decide by yourself" (turn 168). Adding to the teacher's elaboration, Lotta says "and kill the monster" (turn 169). In this way she weaves together her (and Gustav's) suggestion with the teacher's elaboration (the narrative as told in the letters). However, as on the two previous occasions, this suggestion to kill the monster is met by a nonresponse by the teacher, who instead continues her elaboration: "and then you also get, it says here, a power that makes so that when you talk, the dragon cannot hear you" (turn 170). She thus adheres to the rationale as stated in the letter, carrying the story forward.

\section{Excerpt 10.7: Concluding the Play}

186 ANNA: $\quad$ Then you need to be quiet

187 Child: $\quad$ Fruit, hello 


\begin{tabular}{l|l|l}
\hline 188 & ANNA: & $\begin{array}{l}\text { Takes out a bowl of fruit from a small tent: Come, sit down (gets a note from } \\
\text { Annika) what does it say? Mission five. Congratulations, you succeeded with all } \\
\text { your missions. Now you all get magical powers and when you take your first } \\
\text { bite of this magical fruit you receive a magical power (the children each take a } \\
\text { section of an apple from a bowl and eat). And now you can talk, because it said } \\
\text { that when we find this fruit, the dragon could no longer hear us. But Nathan, } \\
\text { Gustav and all, I want to know what magical powers you have (several children } \\
\text { raise their hands) Minna? }\end{array}$ \\
\hline 189 & Child: & Fire \\
\hline 190 & Minna: & Ice \\
\hline 191 & Esther: & Fire also \\
\hline 192 & ANNA: & How about you (points at Eyla)? \\
\hline 193 & Eyla: & Ice \\
\hline 194 & ANNA: & Do you know what my magical powers are? I'm invisible \\
\hline 195 & Gustav: & I know, that I can do everything \\
\hline 196 & ANNA: & You can do EVERYTHING? That was a good magical power \\
\hline 197 & Lotta: & Hit the monster \\
\hline 198 & ANNA: & How about you (turns to Nathan)? \\
\hline 199 & Nathan: & The same as Gustav \\
\hline 200 & ANNA: & Nathan, what's your magical power \\
\hline 201 & Nathan: & Same as Gustav \\
\hline 202 & ANNA: & What did Gustav have? \\
\hline 203 & Gustav: & Everything \\
\hline
\end{tabular}

Sneaking through a foreboding tunnel, the children are presented with a bowl of fruit (magical fruit). Finding the final letter, the teacher reads and congratulates the children on succeeding with all tasks. As a reward of having arrived at and eaten the magical fruit they each acquire a magical power of their own choosing (turn 188). The teacher asks the children what powers they choose. The children give different suggestions, such as "fire" and "ice", "that I can do everything" (turns 189-195), and finally, "hit the monster" (turn 197). In contrast to the suggestion to be able to do everything, this last suggestion is not further commented on by the teacher, who instead goes on asking the remaining children (cf. above on what is and is not institutionally accepted and valued forms of play). The narrative framework established by the teacher constitutes several different magical powers that each child is about to earn through their play. This framework gives the children the opportunity to familiarize themselves with different ideas about what may constitute a magical ability (cooling down lava stones, making monsters sleep or talking without a dragon hearing), that is, with a variation allowing the children to appropriate a wider repertoire to choose from when they reach the final event of the activity (or when playing 'magic' on other occasions): the fruit that when bitten will give them the magical power of their individual choice. 


\section{Discussion}

In this chapter, we have analyzed how a teacher initiates, and children participate in and contributes to developing a mutual imaginary narrative activity. We have shown how in this as-if activity, the children encounter and take on real conceptual problems (as is). In this continuous activity, spanning over $20 \mathrm{~min}$, the teacher manages to engage the children in a mutual problem-solving play project mediated by a narrative frame communicated in sections through text (letters). During the activity, the children are faced with a number of conceptual and coordinating problems they need to take on as a group. In her participation in the activity, the teacher fluctuates between speaking and in other ways acting as if (make-believe) and as is (orienting towards established cultural knowledge). Contents such as shape (form), numbers (what constitutes a set of ten or five), terminology (what are "objects"), coordination of actions and contributions (collaboration, collaborative problem solving, reaching mutual agreement), and text (reading) are actualized and contextualized within the established play frame. The activity further indicates how play in preschool is not free from institutional framing (a feature of the 'freedom' of play not highlighted by van Oers', 2014, previous theoretical elaboration of this concept); rather, participating in play in preschool also means to take part in a socialization process, according to which forms of play differ to what extent they are acceptable and valued. The play develops in a potentially tense 'space' between temporarily sufficient intersubjectivity (allowing the participants to go on with a joint activity/ play project) and alterity (i.e., diversity, suggestions on how to reframe the premises of the activity, or expand it in other ways than previously, implicitly or explicitly, agreed upon). The activity also illustrates what Vygotsky (1997) has emphasized as key to making the cultural tool of text (and the cultural practices of reading and writing) relevant to preschool-age children: they must be necessary for the development of play projects. Reading in the present example is made relevant to the evolving play children are engaged in, rather than something external to it and stand-alone.

As with all play, some premises or rules of the play are established, some initially, others as the play develops. In van Oers' (2014) terms, the play project is not free from the teacher - rather, she is instrumental to it, initiating and organizing it, as well as to some extent taking part in it as a play partner. Critically reflecting on the activity, which has many qualities of play-responsive teaching, it is debatable to what extents the children are free to (van Oers, 2014) take the play in unforeseeable directions (cf. particularly our discussion of alterity, above: we can thus theorize the 'free to' of play as a consequence of how participants, including the teacher, respond to alterity). However, it is clear that the narrative frame (the make-believe world of as if) works in engaging the children in a mutual activity where they actively and in collaboration with each other and the teacher take on conceptual challenges. These challenges are, metaphorically speaking, planted in the play, and important cultural resources are made necessary for the development of the play. This is one way in which teaching in preschool can be play-responsive. 


\section{References}

Björklund, C. (2014). Powerful teaching in preschool: A study of goal-oriented activities for conceptual learning. International Journal of Early Years Education, 22(4), 380-394.

Björklund, C., Magnusson, M., \& Palmér, H. (2018). Teachers' involvement in children's mathematizing: Beyond dichotomization between play and teaching. European Early Childhood Education Research Journal, 26(4), 469-480.

Clarke, S. N., Howley, I., Resnick, L., \& Rosé, C. P. (2016). Student agency to participate in dialogic science discussions. Learning, Culture and Social Interaction, 10, 27-39.

Mercer, N., \& Littleton, K. (2007). Dialogue and the development of children's thinking: A sociocultural approach. London, UK: Routledge.

Pramling Samuelsson, I., \& Pramling, N. (2013). Orchestrating and studying children's and teachers' learning: Reflections on developmental research approaches. Education Inquiry, 4(3), 519-536.

Rommetveit, R. (1974). On message structure: A framework for the study of language and communication. London, UK: Wiley.

van Oers, B. (2014). Cultural-historical perspectives on play: Central ideas. In L. Brooker, M. Blaise, \& S. Edwards (Eds.), The Sage handbook of play and learning in early childhood (pp. 56-66). London, UK: Sage.

Vygotsky, L. S. (1966). Play and its role in the mental development of the child. Voprosy psikhologii, 12(6), 62-76. (Original work published 1933).

Vygotsky, L. S. (1997). The collected works of L. S. Vygotsky, Volume 4: The history of the development of higher mental functions (R. W. Rieber, Ed. \& M. J. Hall, Trans.). New York: Plenum Press.

Vygotsky, L. S. (1998). The collected works of L. S. Vygotsky, Volume 5: Child psychology (R. W. Rieber, Ed. \& M. J. Hall, Trans.). New York: Plenum.

Vygotsky, L. S. (2004). Imagination and creativity in childhood. Journal of Russian and East European Psychology, 42(1), 7-97. (Original work published 1930).

Wertsch, J. V. (1998). Mind as action. New York, NY: Oxford University Press.

Open Access This chapter is licensed under the terms of the Creative Commons Attribution 4.0 International License (http://creativecommons.org/licenses/by/4.0/), which permits use, sharing, adaptation, distribution and reproduction in any medium or format, as long as you give appropriate credit to the original author(s) and the source, provide a link to the Creative Commons licence and indicate if changes were made.

The images or other third party material in this chapter are included in the chapter's Creative Commons licence, unless indicated otherwise in a credit line to the material. If material is not included in the chapter's Creative Commons licence and your intended use is not permitted by statutory regulation or exceeds the permitted use, you will need to obtain permission directly from the copyright holder.

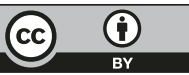

